\title{
María del Mar Sánchez Ramos 2020. Documentación digital y léxico en la traducción e interpretación en los servicios públicos (TISP): fundamentos teóricos y prácticos. Berlín: Peter Lang. 184 pages. ISBN 978-3-631-80849-8
}

Documentación digital y léxico en la traducción e interpretación en los servicios públicos (TISP): fundamentos teóricos y prácticos is the result of several years of research focused on Public Service Interpreting and Translation (PSIT). Its main novelty lies in linking the concepts of digital documentation and lexis with the specific field of PSIT and considering its importance. To this end, the author perfectly combines theoretical and practical elements, which are well organised and delimited throughout the work and which provide this study with scientific rigour.

This work, although it contains a great deal of information, is easy to read, as the wording is always clear and precise and helps the reader to understand all the content. It has 184 pages, which have been organized according to the following structure: introduction, four chapters to be detailed below and conclusions. The bibliography section, which is sufficiently extensive, includes very relevant sources related to the subject discussed in the book. Likewise, the author has included some very updated references that highlight the novelty of the topic treated.

The first chapter is devoted entirely to the state of play of PSIT. This chapter serves as a contextualization of the work. Sánchez Ramos, firstly, takes a conceptual approach to this discipline. The lack of consensus that seems to exist around the definition and denomination of this concept is remarkable. The author qualifies the task of delimiting this concept as "risky" if only a concrete definition is to be given, and she refers us to the work carried out by Cedillo Corrochano (2017) as an excellent analysis of the different definitions provided for this concept. She also reviews different authors who define PSIT, such as Niska (2002), Gouadec (2007), Taibi (2011) or Valero-Garcés (2019). The author then focuses on the different highlights that have marked the development of PSIT in Spain and cites those research proposals that have helped in its evolution. The last part of this chapter is devoted to the state of university education in this field. Sánchez Ramos confirms that, at present, there are various training proposals in Spain and details in depth the master's degree offered by the University of Alcalá (Spain), called Máster universitario en comunicación intercultural, interpretación y traducción en los servicios públicos ${ }^{1}$. As a conclusion to this chapter, the author reflects on the need for specific linguistic and cultural knowledge for this modality of translation and interpreting and asks herself a question that she will develop in the following chapters: what are the needs that a translator and interpreter in public services must acquire and develop?

The second chapter is dedicated to the importance of the lexis within the discipline of translatology. In this chapter, the author also carries out a detailed analysis of the concept of translation competence. With these data, Sánchez Ramos tries to find an answer to the question: should the lexical component be restored in order to improve the training of translators and interpreters in public services? Throughout this chapter, a very exhaustive review is made of different pro-

1 University master's degree in intercultural communication, interpretation and translation in public services 
posals regarding the different competencies required in the work of translation and interpreting. From communicative competence, firstly, as defined by Canale/Swain (1980), to translation competence, from the perspective of authors such as Bell (1991), Hatim/Mason (1997), Presas (1996, 1998), Neubert (2000), PACTE group (2000, 2001, 2003, 2009, 2011) or Kelly (2002). Finally, the author describes the last steps taken in the definition of the concept of translation competence, related to technology, thanks to the definition established by the EMT (2009). This overview of the different authors in relation to translation competence allows us to observe that the lexical component is present in the different proposals and, therefore, the author concludes this chapter by responding to the question that was initially posed in an affirmative manner, that is, yes, the lexical component should be recovered in order to improve training in this field.

The third chapter is focused on the contextualization of lexis in translator training and to knowing what place it occupies in the different existing models. For this purpose, Sánchez Ramos reviews the most relevant studies on translator training, from the most traditional ones, such as $\mathrm{Ne}-$ wmark (1988) or López Guix/Minett-Wilkinson (1997), to didactic models offered by Hurtado Albir (1999) or Robinson (2003). Likewise, some proposals from the field of second language teaching are added to this review. Here, authors such as Richards (1976), Wilss (1990) and Lewis (1993) are cited. This chapter concludes with a very interesting proposal by the author for the development of lexical translation competence applied to PSIT. This competence, as indicated by the author, would answer the question: what does a translator and interpreter need to know in order to know a word in depth? This proposal can be extremely useful, as it can be used as a starting point in the academic field to enhance the lexical resources of the translator and interpreter in this field.

The last chapter is dedicated to digital documentation and its connection to PSIT. The importance of the information included here is given by the changes to which the sector has had to adapt due to the development of the technological era. These changes have not only affected the practice of the profession, as Sánchez Ramos points out, but have also been reflected in the other phases of the translation process, such as documentation. In this chapter, the author first approaches the concepts of documentation and digital documentation, and then links it to the field of translation and interpreting in the public sector and to technology. The author then lists several digital resources that should be included in the training of the discipline, as she considers them fundamental: electronic lexicographic sources, corpus and concordance programs, machine translation and post-editing tasks.

In the conclusions of the study, the author points out that this work aims to contribute to the consolidation of PSIT by serving as a starting point for studies on the lexical and documentaryrelated needs within this field. For all these reasons, this book could be highly useful for both teachers and researchers, as well as for those agents involved in the public sector who are interested in learning more about the translation and interpreting sector.

\section{References}

Bell, Roger 1991: Translation and Translating. London: Longman.

Canale, Micahel/Swain, Merrill 1980: Theoretical Bases of Communicative Approaches to Second Language Teaching and Testing. In Applied Linguistics 1, 1-47.

Cedillo Corrochano, Carmen 2017: La Presencia Mediática de la Traducción e Interpretación en Los Servicios Públicos a Través de Análisis de Discursos en La Red. PhD thesis. Alcalá de Henares: Universidad de Alcalá.

EMT 2009: Competences for professional translators, experts in multilingual and multimedia communication [online]. https://ec.europa.eu/info/sites/info/files/emt_competences_translators_en.pdf (accessed 04 March 2020).

Gouadec, Daniel 2007: Translation as a Profession. Amsterdam: John Benjamins Publishing.

Hatim, Basil/Mason, Ian 1997: The Translator as Communicator. London: Routledge.

Hurtado Albir, Amparo 1999: Enseñar a Traducir. Madrid: Edelsa.

Kelly, Dorothy 2002: Un Modelo de Competencia Traductora: Bases para el Diseño Curricular. In Puentes 1, 9-20.

Lewis, Michael 1993: The Lexical Approach. London: LTP. 
López Guix, Juan/Minnet-Wilkinson, Jacqueline 1997: Manual de Traducción Inglés-Castellano. Barcelona: Gedisa.

Neubert, Albrecht 2000: Competence in Language, in Languages, and in Translation. In Schäffner, Christiana/Adab, Beberly (eds.), Developing Translation Competence. Amsterdam: John Benjamins Publishing, 3-18.

Newmark, Peter 1988: A Textbook of Translation. London: Prentice Hall.

Niska, Helge 2002: Community Interpreter Training: Past, Present, Future. In Garzone, Giuliana/Viezzi, Maurizio (eds.), Interpreting in the 21st Century: Challenges and Opportunities. Amsterdam: John Benjamins Publishing, 133-144.

PACTE 2000: Acquiring Translation Competence: Hipothesis and Methodological Problems in a Research Project. In Beeby, Allison/Ensinger, Doris/Presas, Marisa (eds.), Investigating Translation. Amsterdam: John Benjamins Publishing, 99-106.

PACTE 2001: La Competencia Traductora y su Adquisición. In Quaderns, 6, 39-45.

PACTE 2003: Building a Translation Competence Model. In Alves, Favio (ed.), Triangulating Translation. Amsterdam: John Benjamins Publishing, 43-66.

PACTE 2009: Results of the Validation of the PACTE Translation Competence Model: Acceptability and Decision Making. In Across Languages and Cultures 10(2), 207-230.

PACTE 2011: Results of the Validation of the PACTE Translation Competence Model: translation Project and Dynamic Translation Index. In O’Brien, Sharon (ed.), Cognitive Explorations of Translation. London and New York: Continuum, 30-45.

Presas, Marisa 1996. Problems de Traducció i Competència Traductora. Bases per a una Pedagogía de la Traducció. $\mathrm{PhD}$ thesis. Bellaterra: Universidad Autónoma de Barcelona.

Presas, Marisa 1998: Los Componentes de la Competencia Pretraductora en el Marco del Diseño Curricular. In García Izquierdo, Isabel/Verdegal, Joan Manuel (eds.), Los Estudios de la Traducción. Un Reto Didáctico (131-134). Castelló, 131-134.

Richards, Jack 1976: The Role of Vocabulary Teaching. In TESOL quarterly 10(1), 77-89.

Robinson, Douglas 2003: An Introduction to the Theory and Practice of Translation. London: Routledge.

Taibi, Mustapha 2011: Public Service Translation. In Malmkjaer, Kirsten/Windle, Kevin (eds.), The Oxford Handbook of Translation Studies. Oxford: Oxford University Press, 214-227.

Valero-Garcés, Carmen 2019: Intercultural Communication. Public Service Interpreting and Translation. In Valdeón García, Roberto/Vidal Claramonte, África (eds.), The Routledge Handbook of Spanish Translation Studies. London: Routledge, 211-226.

Willis, David 1990: The Lexical Syllabus. London: Collins Cobuild.

Lorena Pérez Macias Facultad de Filosofia y Letras Universidad Autónoma de Madrid E-mail:lorena.perez@uam.es 